\title{
A transnational networked space: tracing residential tourism and its multi-local implications in Costa Rica \\ Femke van Noorloos
}

Author manuscript published as article in International Development Planning Review (IDPR), 2011, 33 (4), pp. 429-444, https://doi.org/10.3828/idpr.2011.22

(C) 2017. This manuscript version is made available under the CC-BY-NC-ND 4.0 license http://creativecommons.org/licenses/by-nc-nd/4.0/

\section{Dr. Femke van Noorloos}

International Development Studies, Dept. Human Geography \& Planning, Faculty of Geosciences, Utrecht University, The Netherlands, H.J.vanNoorloos@uu.nl

\begin{abstract}
The complexity of recent residential tourism growth on Costa Rica's coasts calls for new approaches that address this phenomenon and its implications in a more mobile and trans-local way. In this article one growing residential tourism destination is analysed as a transnational networked space. The focus is on three flows or corridors which have enabled the growth of residential tourism and through which its implications spread in space. These flows of people and investment from North America, Nicaragua and central Costa Rica have not been established automatically: they build on a history and have been reinforced. This does not mean that local groups are left without opportunities; however, some of them increasingly experience a disconnection from mainstream national development.
\end{abstract}

\section{Introduction}

Residential tourism figures prominently among current mobility phenomena: between tourism and migration, this activity constitutes a particularly interesting subject to research post-modern, mobile lifestyles and globalisation 'on the ground'. At the same time, the residential tourism industry, with its focus on land transactions and urbanisation and its increasing penetration into peripheral developing regions provides an urgent research topic in development studies. Residential tourism engenders multiple linkages to and from local space: it entails an influx of foreign residents, short-term tourists, investment and labour migrants, with an associated range of financial and cultural linkages. 
Residential tourists can be thought of as being on a continuum between permanent migration and tourism (Hall and Williams, 2002). A main feature and difference with short-term tourism is that residential tourists establish themselves temporarily or permanently in another country or region by buying (or sometimes renting) a private residence there. Furthermore, residential tourists differ in many ways from labour migrants too, since leisure, lifestyle and cost of living (rather than labour) are key factors in their migration and stay (Benson and O'Reilly, 2009). ${ }^{1} \quad$ The literature on residential tourism has led to important understandings of this relatively new phenomenon, for example on its implications for local socioeconomic development and power relations in the destination areas (Aledo, 2008; McElroy and de Albuquerque, 1992; Román, 2008; McWatters, 2009; Cañada, 2010; Janoschka, 2009). However, what seems to be missing in the recent debate is a sense of how residential tourism, besides being in itself an expression of complex current forms of mobility and transnationality, also produces profound trans-local effects that are not limited to the destination areas. Despite the recent 'mobility turn' in social science, in which static research objects make way for travelling paths and mobile lifestyles (Urry, 2007), studies of residential tourism rarely apply such mobile and multi-local approaches.

Some insights from 'short-term tourism' literature are useful here. Torres and Momsen (2005) argue that an international tourism resort such as Cancún can best be analysed as a 'transnational space'. Hence they analyse the effects of Cancún's tourism development not only in terms of local socio-spatial effects, but also in terms of its connections to different areas through production-related and consumption-related migration flows. A multi-scalar view of transnationalism is played out in Cancun, with multinational tourism franchise agreements, international tourist flows, national government development strategies, domestic tourism industry investment, and migration-related livelihood strategies at the household level all coming together. This is expressed locally in a transnational networked space with complex and profoundly unequal spatial arrangements. However, tourism's effects stretch far beyond the boundaries of the tourism destination itself.

For a detailed analysis of the global-local nexus René van der Duim's work on actor-networks in tourism is also useful. He argues that globalisation is not an automatic and uninterrupted flow affecting localities through tourism: rather, for a tourism project or destination to emerge, specific methods are needed to bring together entities and actors that are sometimes radically different or distant. These are the processes of translation (Van der Duim, 2005, 2007). Other works on the ethnography of globalisation have contributed in a similar way to constructing an elaborate view of global-local connections: Anna Tsing's idea that aspirations of global connection come to life in friction, the grip of worldly encounter, is useful here too (Tsing, 2005).

\footnotetext{
${ }^{1}$ As a result of the confusion around its definition, in the literature different labels have been adopted: lifestyle migrants, retirement migrants, amenity migrants and second-home owners (Benson and O’Reilly, 2009; McIntyre, 2009). I will here use the term residential tourism, firstly to account for the importance of not only retirees but also younger migrants; and secondly in order to focus attention on its close relationship with short-term tourism.
} 
In this article I trace the three main flows of people and capital that have enabled the development of a residential tourism destination in Costa Rica, and that function as 'development corridors' through which development effects are canalised to other areas. I analyse how these flows and connections were established through specific interactions and imaginaries. Based on these 'development corridors', I analyse how the implications of residential tourism are multi-local, travelling and diffuse, rather than static and local. The geographical focus of this paper is the Costa Rican northwest coast (Guanacaste province), where residential tourism has experienced notable growth from about 2002 up to 2008, mainly directed by the North American market. The first flow is then between North America and Guanacaste: a diverse flow of investment and human mobility from the US and Canada into Guanacaste has been at the root of residential tourism development. Second, the Nicaragua-Guanacaste flow will be dealt with: human mobility along this corridor has been an important enabling factor for the residential tourism industry, and development effects are transferred back into Nicaragua. Lastly, an internal flow in Costa Rica will be dealt with: the Central Valley-Guanacaste domestic corridor. Economic linkages along this corridor have been intensified by residential tourism, complemented by human migration; as such, this flow is also important in assessing development impacts. ${ }^{2}$ Before analysing the corridors I will describe some basic characteristics of residential tourism in Costa Rica.

\section{Residential tourism in Costa Rica}

In the first decade of the $21^{\text {st }}$ Century residential tourism in Central America experienced dramatic growth, with Costa Rica, Panama and Mexico figuring among the most prominent destinations, while other countries such as Nicaragua have been growing in importance. Costa Rica has been a popular relocation destination for US and Canadian citizens since the 1970s, with flows that to focus mainly on the urban central valley area of the country. Since about 2002, the country's Pacific coast has experienced a residential tourism boom, making the phenomenon more spatially concentrated and visible. However, from 2008 the financial crisis has put a halt on the boom, and recovery has been slow. Official population numbers hardly come close to quantifying residential tourism, as temporary populations are left out; but according to rough estimates, 50,000 North American citizens (forming about $1 \%$ of the national population) were estimated to have their residence in Costa Rica in 2010 (pers.comm. ARCR Costa Rica), whereas in 2009 estimates were still between 30,000 and 40,000 (Janoschka, 2009).

In Costa Rica the enhanced importance of residential tourism and the real estate industry more generally is reflected in foreign direct investment (FDI): whereas tourism and real estate respectively made up 15 per

\footnotetext{
${ }^{2}$ The empirical material for this article was collected during two periods of ethnographic fieldwork in the areas of Tamarindo and Playas del Coco, Costa Rica: in May-December 2008, and September-November 2009. These includes more than 50 interviews with inhabitants of different origins as well as leaders of organisations and activists; in addition, participant observation was used, e.g. during associations' meetings and informal conversation. Besides the empirical material, this article uses secondary sources from academics, archives, media and internet blog sources to trace the different flows into Guanacaste..
} 
cent and 5 per cent in 2003, by 2007 these percentages had increased to 17 per cent for tourism and 34 per cent for real estate (BCCR, 2008). In the two main micro-regions of tourism development in Guanacaste (the Tamarindo area and the Playas del Coco area), a total of 145 completed residential tourism projects were identified in 2010 (van Noorloos and Zoomers, 2010), with a very conservative estimated total of almost 8,000 plots, houses or apartments. The majority were relatively small apartment complexes, but there were also eight large projects of more than 200 entities. In addition, 45 more projects were announced but their construction was halted or had not yet started (often due to the post-2008 financial crisis); these included some very large projects. Investment in tourism and real estate was mostly of foreign origin: almost 75 per cent of the project developments were at least partly of North American origin, whereas 35 per cent were at least partly of Costa Rican origin. Combinations of both were also common. This reflects how Costa Rica's residential tourism industry mainly caters for the North American market: for example, between 2004 and 2007, 55.2 per cent of FDI in real estate in Costa Rica was from the US, followed by Canada (7.5 per cent) and Germany (4.8 per cent) (BCCR, 2008). A combination of individual land and house sale and many different types of more formal and pre-arranged development projects makes for a complicated industry.

\section{The North America - Guanacaste corridor}

Residential tourism has brought new flows of human migration, tourism and investment to the Costa Rican northwest coast, mainly from the US and Canada. The North America-Guanacaste connection is not new, however. Already by the 1880 s a few US citizens acquired very large livestock haciendas in Guanacaste (Edelman, 1992). Until the 1970s, there was a large beef export industry from Guanacaste to the US, and North Americans invested huge amounts of money in land in Guanacaste. Processes of foreign land acquisition for high prices, together with other factors, made Guanacaste a space for speculation, concentration and subutilisation of land (Edelman, 1992). This development also had its effects in coastal areas of Guanacaste, where the first speculators and investors, foreign and national, bought land in the 1970s, and land buying intensified in the 1980s. ${ }^{3}$ These investments were already made with a view to future tourism and urban development, as tourism was growing in what was by then an economically depressed area.

The Costa Rican government was quick to recognise the region's potential for attracting tourism and foreign retirees, but the incentives and policies it put in place did not have the intended effect in

\footnotetext{
${ }^{3}$ For example, the area of Playa Grande was bought in the 1970s by Robert Vesco, a North American. The area of Pinilla was bought in 1974 by Hoover Gordon Pattillo, a North American investor who started developing it as a residential community in the 1990s. A multinational group of developers bought the land for Reserva Conchal in the 1980s. North American real estate brokers have been active since early years: Century 21 was established in the area in 1977.
} 
Guanacaste. ${ }^{4}$ Until the 1990 s there were only a small number of exploratory international tourists, some of whom established themselves in the area. However, by 2002 the Guanacaste coast had become an international tourism destination with a diverse tourism cluster (Hein, 2002): hotels in all different ranges, restaurants, tour operators, guides, souvenir shops, and transportation companies. Many business owners were foreign. The real estate market was active and a number of residential communities had been established. But the pace of development the region was about to experience was unprecedented. In the next few years, a real estate and residential tourism boom would be created, and Guanacaste's connection to international investors, developers, tourists, and migrants, particularly in the US and Canada, would be greatly intensified.

The success of the privatist and laissez faire-type 'development regime' in attracting more flights and better airport infrastructure and putting the region on the map, was a main trigger in developing Guanacaste coast as a residential and large-scale tourism destination (Janoschka, 2009; Morales and Pratt, 2010). North American tourism and real estate developers and investors secured their investments, often in collaboration with national developers and investors, through national government support. ${ }^{5}$ In addition to a few large 'pioneer' developments, there was also a chaotic proliferation of other developments and initiatives in the real estate and construction industry: apartment complexes, land urbanisations, vacation home complexes, luxury home projects. Most of these were also developed and bought by North Americans (Van Noorloos and Zoomers, 2010). Another important push towards residential tourism was caused by innovations in the tourism industry that were brought into Costa Rica: investors and hotel chains, mostly from the US and Spain, introduced combinations of short-term tourism and real estate/residential products. Tourists are a perfect target for the real estate industry to buy property: the tourist's desire to experience and gaze at different things (Urry, 1990) is easily converted into a desire to own. On the other hand, finance and investment for new residential communities and vacation home complexes can be attracted partly from the home buyers themselves, which lowers the need for own investment. ${ }^{6}$

However, these factors relating to the development regime and the changing tourism offer are not sufficient to explain the boom in residential tourism. How did Guanacaste manage to attract so many North American residential tourists, investors and speculators? While there are naturally a number of important structural

\footnotetext{
${ }^{4}$ Incentives included the 1964 special pensionado law that offered advantages to foreign retirees establishing in Costa Rica, and the planned development in 1978 of a national tourism resort in Guanacaste, the Papagayo Gulf Tourism Pole. The resort failed to meet expectations in its first two decades, as most of the land concessions were not used (Salas Roiz, 2010).

${ }^{5}$ This support was given, for example, through de facto policies of coastal land privatisation (e.g. government given out multiple concessions of coastal land to a developer; not only in the Papagayo project but in general); turning a blind eye on environmental and other irregularities in tourism projects; applying 'declarations of national interest' to certain tourism projects to bypass strict environmental regulations; supporting a new law on easier approval of marinas; and establishing a public-private partnership for water provision to Guanacaste coastal areas (van Noorloos and Zoomers, 2010).

${ }^{6}$ Often the apartments and houses are subsequently used as vacation rental properties (through a property management company), thus functioning as a sort of hotel, but without the same need for investment. In addition, another increasingly popular feature imported from the US are timeshare arrangements and partial ownership..
} 
factors in North American society that have been important ${ }^{7}$, global capitalism creates an economy of appearances, as Tsing (2005) asserts, investors' choices are partly driven by their dreams, desires and imaginations. Indeed, North Americans project a number of dreams and desires onto Costa Rica and Guanacaste: these have to do with a longing for coastal 'pura vida' living, a relaxed lifestyle surrounded by nature and beach, a prolonged holiday, as directly opposed to their home country lives and retirements which they portrayed as enduring work stress, personal stress and 'rat race', and more ${ }^{8}$ (see also McWatters, 2009). Though not all property owners have personal tourism-related interests, many investors in real estate are lured by the promises of quick and large profits. 'Costa Rica property' was until recently seen by many as an easy and cheap investment with guaranteed profits. The powerful ideas of a global real estate market and 'the world as a retirement destination' have been key to imagining the possibility of foreign real estate investment and residential tourism in Costa Rica. The 'international' (or rather, North American) real estate sector not only profits from the idea of an open, globalised world, but it has actively contributed to the making of globality in real estate investors' minds. Central America was one of the new frontiers of the real estate industry. However, the extension of real estate markets into new developing countries was not an automatic flow of market forces: the privatisation and individualisation of land worldwide have greatly contributed to this. In accordance with the ideas and practices on land titling and security of property promulgated by international institutions such as the World Bank and the InterAmerican Development Bank, people all over the world can now buy land almost wherever they want, provided they have the financial resources (Zoomers, 2010).

As the residential tourism boom has expanded, flows of people have become more self-sustaining: through personal transnational networks and a transnational business climate that has evolved around residential tourism, North Americans who owned property in Guanacaste have brought in new home owners as well as short-term tourists. The flow of residential tourists coming into Guanacaste from North America, most of whom only live part-time on the property or use it as a vacation home or investment ${ }^{9}$, is not only complemented by frequent short-term tourism flows, but also by a variety of other immigrants from the US and Canada: developers, business owners, real estate brokers, and labour migrants. It is important to also consider these related flows of people: while most residential tourists themselves are not yet established in the area year-round, these other migrants often do have a more visible presence. Developers' offices and real estate companies tend to be owned by North Americans, while they hire national as well as foreign

\footnotetext{
${ }^{7}$ A number of structural factors originating in 'the West' or in the US and Canada more specifically, are often mentioned as important factors behind the growth in and potential for retirement migration: demographic factors in the US and Canada (current and future growth of retirement-aged generation), increasing health costs and decreasing retirement pensions in the US, cheap interest rates in the US (before financial crisis), and current generations retiring in the near future have become used to international travelling. Also, general factors relating to increased time-space compression are often mentioned, such as cheap and quick travel and improved and cheaper long-distance communication possibilities (McWatters, 2009; MPI, 2006).

${ }^{8}$ From analysis of eight Costa Rica residential tourists' blogs, 2010

${ }^{9}$ At Hacienda Pinilla, 80 per cent of home and land buyers were from the US (Morales Chavarría, 2005). Most of them used their property as a second home or investment, rather than as a full-time home. At Reserva Conchal, 50 per cent are from the US (www.reservaconchal.com). At Pacífico, 43 per cent of buyers are from the US, and 5 per cent are Canadian. 48 per cent purchased their property as an investment, 31 per cent as a second home, and only 16 per cent as a primary residence (www.pacificocostarica.com)
} 
personnel: in a survey of 16 real estate companies established on the Guanacaste northwest coast with presence on the internet, all owners were either North American (majority) or European. Among the associated brokers and employees of these real estate offices, 57 per cent were from North America or Europe, whereas 43 per cent were from Latin America, most from Costa Rica. ${ }^{10}$ Field observations and informal conversations made clear that in the timeshare business around Playas del Coco many North Americans as well as Europeans were employed. Many different small tourism businesses are also operated by North Americans: restaurants, bars, hotels, hostels and tour companies.

The differential involvement of all these diverse groups of North Americans, some of whom have been attracted to the area by specific employers, others have come to try their luck in employment or business, whereas still others were attracted for lifestyle reasons, makes it difficult to conceptualise and analyse 'gringo' involvement as one powerful globalisation flow.

\section{The Nicaragua - Guanacaste corridor}

However, the North America- Guanacaste connection is not enough to make a residential tourism boom possible. There are other corridors which have contributed to the boom, and which should be taken into account when analysing the sector's effects. One of them is the labour migration connection between Nicaragua and Guanacaste.

It is estimated that 14 per cent of Nicaraguans live abroad, and the largest group lives in Costa Rica: an estimated 335,000 Nicaraguan migrants in 2005 (Baumeister et al., 2008), making up almost per cent of the national population. A considerable part of them lives in north-west Guanacaste: in the coastal districts of Nacascolo, Sardinal, Cabo Velas and Tamarindo, respectively 11 per cent, 10 per cent, 12 per cent and 5 per cent of the population counted in the 2000 census were from Nicaragua (INEC, 2000). Many of them have migrated long ago: during the 1980s Nicaraguans coming into Costa Rica were mostly political and war refugees, whereas in the $1990 \mathrm{~s}$, after the peace agreements, these flows quickly made way for more economically driven labour migration (Morales and Castro, 2002; Baumeister et al., 2008). Besides these permanent migrants, there are also a large number of seasonal and temporary migrants that enter Costa Rica each year.

The phenomenon of temporary migration from Nicaragua (particularly Rivas) to Guanacaste was greatly reinforced by the real estate and construction boom from about 2002; as residential condominium blocks, houses and commercial centres filled the coastal landscape, the construction sector was in constant need of a low-skilled, flexible and cheap labour force. In Costa Rica, 65 per cent of construction workers is Nicaraguan (Bolaños Céspedes, 2009); and it was estimated that in 2008 and 2009 respectively 60,000 and

\footnotetext{
${ }^{10}$ These numbers may be somewhat biased towards officially established real estate companies; however, there is no indication that numbers more informal real estate brokers would be much different.
} 
77,000 workers would be needed in construction in Guanacaste and Jacó; however, with the economic crisis 19,000 jobs were lost (Eirene-Cenderos, 2009). Nicaraguans also carry out a number of other tasks related to the residential tourism sector: men work in gardening and as security guards, whereas women do domestic work and in restaurants. Labour opportunities in the Costa Rican tourism and construction industry have provided an extra poverty alleviation strategy to Nicaraguan young men and women, a safety valve in the face of a lack of labour opportunities and possibilities of maintaining a decent livelihood back home. ${ }^{11}$ Whereas in Guanacaste the Costa Rican labour force has moved towards tourism and real estate activities, Nicaraguans carry out the low-paid and low-skilled work.

The northwest of Costa Rica and the southwest of Nicaragua, being border areas, have traditionally maintained close economic, social and cultural links. Nicaraguan circular migration between Rivas and Guanacaste has been common since the second half of the $19^{\text {th }}$ century (Edelman, 1992; Baumeister et al., 2008). More than forty years ago Nicaraguan peasants without land started to migrate to sugar cane plantations in Costa Rica in a temporary migration flow. From the 1990s migration from Rivas became a mass phenomenon, as sugarcane plantations in Nicaragua were closed (Baumeister et al., 2008). Thus the residential tourism industry is now benefiting from that established migration corridor, which is kept in place and extended through labour opportunities, social networks and cultural imaginaries.

With a strong migration corridor in place, recruitment in the construction industry mainly takes place in Costa Rica, as many Nicaraguans (irregular migrants or with a tourist visa) offer their labour on site. Domestic workers' recruitment occurs through personal networks: women, either living in Nicaragua or already in Costa Rica, are recommended by a family member or friend in Costa Rica, who will be a guarantor (Baumeister et al., 2008). A good deal of the construction-related migration in Guanacaste is flexible, volatile, temporary and irregular in nature. According to the Costa Rican social security institute, 73 per cent of construction workers in Guanacaste (all nationalities) lack social security cover (OIM/AECID/MTSS 2009, in Bolaños Céspedes, 2009, p. 20-21). The great fragmentation and subcontracting of project contracts in the construction industry makes orderly and lawful labour recruitment difficult (Bolaños Céspedes, 2009). Domestic work is also associated with low levels of social security coverage (Eirene-Cenderos, 2009).

To investigate development effects of residential tourism in Costa Rica, the migration chain should be followed back to Nicaragua to see how Costa Rican employment affects families there. While some authors argue that remittances from Costa Rica to Nicaragua have strong implications for poverty alleviation and more equal income distribution (Monge et al., 2009), others are more critical: Morales and Castro (2002) argue that migration is not a way out of poverty for most households, but merely a survival strategy that may reproduce poverty on a binational scale. In the specific case of out-migration from Rivas to Costa

\footnotetext{
${ }^{11}$ For a construction worker, the minimum salary is $\$ 15$ a day in Costa Rica, and $\$ 1$ per hour in Nicaragua. A domestic worker earns a minimum wage of $\$ 265$ a month in Costa Rica, compared to real wages of US\$50-US\$100 in Nicaragua.
} 
Rica, the study by Baumeister et al. (2008) gives a number of indications on its effects on development. Temporary migrants' remittances are mostly spent on consumption of basic goods; and sometimes on house improvement, household goods, cell phones, clothes; or to pay debts. When the migration is more prolonged and in a regular manner, remittances are higher and allow for more investment in housing, furniture, household goods, and in study.

Thus the flows of money from Guanacaste to Nicaragua contribute to poverty alleviation, but the impacts this labour migration will have on Nicaraguan communities in the long-term are doubtful. Especially in the construction sector, the financial crisis has strongly reduced labour opportunities ${ }^{12}$; in general, construction and real estate booms such as the one in Guanacaste are necessarily limited in time. Besides that, adverse labour conditions - low social security coverage, risky work environments etc.- make it clear that personal wellbeing and empowerment might be severely sacrificed in the process. On the other hand, the residential tourism industry also provides opportunities in other sectors such as domestic work, restaurants, security and in retailing. These are often carried out by permanent migrants, who often have their families established in Costa Rica (see also Steel, Winters and Sosa, 2011, in this collection).

In interviews in 2009, in the midst of the financial crisis and real estate crisis in Guanacaste, Nicaraguan inhabitants without exception emphasised the importance of tourism and construction for employment. They had taken advantage of the job opportunities offered by foreign investment, and depended on 'foreigners' and tourism as a source of income.

I'm jobless now, but if I manage to find a job I would like to work about a year and a half longer and buy a lot in Nicaragua, build my own house there. Here you can't do that. Having a job I could invest the money there: to build a house, maybe put up a business, it could help me a lot. I always sent money to Nicaragua each month, 100, 80 or 70 dollars, but now I can't.

(interview 29 October 2009: Nicaraguan construction worker who had lived for four years in Playas del Coco)

(...) my partner is now without a job. Some time ago he entered again at Matapalo (Hotel RIU), and he worked there for 28 days, now he's still waiting for his pay. We have to wait what comes up, but he doesn't have a steady job. Now to help with the house income I do things like vending, I sell corn, I make tamales, and sometimes I sell cosmetics, to help. (....) Sometimes I send money to Nicaragua, but not a lot, not monthly. When you have your children in Nicaragua you get used to sending money each month, but my children have always been here with me.

(interview 28 October 2009: Nicaraguan woman who had lived for eight years in Costa Rica, Playas del Coco)

\section{The Central Valley - Guanacaste corridor}

A third corridor that has been strengthened by residential tourism is a domestic one between the Costa Rican centre (the Great Metropolitan Area, to be called GAM, comprising areas of high population density

\footnotetext{
${ }^{12}$ In fieldwork interviews and observations in 2009 it was confirmed that many Nicaraguans who worked in construction have returned to Nicaragua or turned to agricultural work due to a lack of opportunities.
} 
including the capital, San José, and other cities Alajuela, Heredia and Cartago) and the Guanacaste coastal area. First, economic flows have been strengthened, with many companies from the GAM investing in the area. In his study of tourism in two coastal regions in Costa Rica, Hein (2002) points out how economic backward linkages of tourism tend to benefit agricultural producers from central Costa Rica, rather than provide local and regional producers in the tourism areas with opportunities. In the same vein, Hein further argues, construction companies that work in the tourism industry are also mainly based in San José, thereby producing national 'linkages' while not contributing to regional business. This bias towards the Costa Rican metropolitan area to the detriment of regional localities has been further reinforced by the emergence of residential tourism. With an increased focus on construction, and the construction industry in Costa Rica mainly coming from the central area, the connection between Guanacaste and the GAM was intensified. ${ }^{13}$ Besides that, other businesses based in and around San José established new linkages and branches in coastal provinces: developers, banks, large supermarkets, private hospitals, private security companies, lawyers' offices, and car rental companies.

With the arrival of new businesses from the national centre, workers were also attracted from outside the region. As educational opportunities in the hitherto peripheral area were largely lagging behind the needs of the tourism industries, highly skilled employees in real estate, project developing, tourism and construction were often brought in from the GAM. They were offered good labour conditions and some were attracted by a tourist lifestyle near the coast. Besides the highly-skilled, other people from the GAM came to the area as well, albeit in more self-organised ways: some because of family ties, others for low-skilled work or establishing small businesses. Guanacaste has in the past had a negative migration balance for decades and is known as a province of out-migration, with flows particularly tending towards the GAM (classic ruralurban migration). This situation has now changed as a consequence of the economic growth related to tourism, at least in the coastal districts and in the capital of Guanacaste, Liberia: these areas have turned into economic focal points. In recent years many young people from the centres are seeking their fortune on the coasts. Also, families that had migrated to other regions in earlier decades have come back to the area. While Guanacaste was still a province of net out-migration in the 2000 census, during the 1995-2000 period the migration balance had become less negative. This development seemed to continue into the $21^{\text {st }}$ century: household surveys from 2004-2007 show only a slightly negative migration balance in Guanacaste (when comparing people's place of residence two years ago with their current place of residence); and for 2009 there was even a positive migration balance, with a large number $(11,400)$ of internal migrants, were mostly from the GAM region, but also from other regions such as the North and Atlantic (INEC, n.d.). The 2008 household survey is illustrative in that, of those occupied in the sector of real estate, company development and renting activities, only 48 per cent were from Guanacaste (in other provinces this number is between 60 and 80 per cent); whereas 21 per cent were from the central valley (INEC, n.d.).

\footnotetext{
${ }^{13}$ However, subcontracting and fragmentation are characteristic for the construction industry in the area; the subcontracting firms are often from the region itself. Still, the main financial flow links back to the large companies in the centre .
} 
This influx of Costa Ricans from the GAM into marginal areas in turn gave a new impulse to the real estate and construction industry, as they entered the renting market. Many Costa Ricans also invested in land and houses in Guanacaste as a vacation home property or investment. ${ }^{14}$ With increased human and financial linkages between Guanacaste and the GAM, it becomes clear that one of the groups profiting from the real estate and residential tourism boom has been the central-Costa Rican middle class (and elites). Young employees have benefited from well-paid job opportunities, and investors and business owners have seen good business and returns to investment, at least until the crisis.

\section{Conclusion: space for trans-local development?}

Tsing describes how local, national and international configurations, events and ideas come together in a certain locality to produce specific effects, as opposed to the idea of global flows arriving in predictable ways (2005). In Guanacaste, the corridors and flows of North American investment and migration, Costa Rican central valley investment and migration, Nicaraguan migration, and local governments, business owners and communities came together and produced a residential tourism boom, thereby converting the coast into a transnational space (Torres \& Momsen, 2005). This was not an automatic and uninterrupted flow of simple capitalist forces: structural factors, historical circumstances and purposive action brought the three flows into Guanacaste and made for a complex and diverse development.

Two broad qualification remarks should be made. First, the aim of the discussion has not been to deny the existence of other migration and investment flows, such as those from Europe or South America; but these are generally smaller. Second, it would be wrong to argue that local populations are left without any employment or investment opportunities because of all these transnational flows. A considerable number of local and regional people from Guanacaste do find employment in the tourism, real estate and construction sector (see also Programa Estado de la Nación, 2007); and there are locally-owned businesses. However, the benefits and drawbacks of tourism and real estate are unequally distributed: a number of nearby towns can benefit from employment, whereas others deal with negative externalities such as water scarcity; and various population groups, such as local families living off fishery in Playas del $\mathrm{Coco}^{15}$, are left outside the tourism economy.

The only jobs that companies offer us here is like construction and things like that, they don't offer good jobs because those jobs always go to people from outside. The thing is that it's not enough anymore to speak English, you have to speak several foreign languages now. And that's how people get isolated. (....) The problem is also that we are mothers with small children, we cannot have a permanent job because we have to take care of the children, and also the salaries are very low in general; it's not even enough to pay someone to take care of your kids. Interview inhabitant Matapalo, 17 November 2008

\footnotetext{
${ }^{14}$ At Pacífico residential community, 48 per cent of the owners are from Costa Rica (www.pacifico-costarica.com); at Reserva Conchal, this is more than 20 per cent (www.reservaconchal.com)

${ }^{15}$ Interviews Playas del Coco, September/October 2009
} 
The crucial question is whether increased trans-local connections flowing from residential tourism can provide people with better opportunities to lead valuable lives; whether they contribute to development. Applying a trans-local analysis - rather than automatically focusing on the local - complicates every evaluation of residential tourism's development potential. It shows that some local people may become increasingly disconnected by residential tourism, even in spite of physical proximity; whereas new opportunities are given to more distant employees and businesses. Development implications travel in space, towards Nicaraguan hometowns of migrants and the Costa Rican centre.

These trans-local implications further complicate any assessment of residential tourism's implications: for example, there is no consensus on the structural effects that Nicaraguan employment in Costa Rica's residential tourism industry has on development in Nicaragua. What is more, such a trans-local analysis reminds us of a number of biases in development research and in migration and development debates (see also Raghuram, 2009): Nicaraguan migrants are seen as 'development subjects', they are either seen as in need of being developed or they are made co-responsible for the development of their country of origin. On the other hand, domestic Costa Rican migrants, often from middle class backgrounds, are regarded as individuals in search of personal empowerment opportunities. The same is true for residential tourists, who in addition often feel a desire or even moral pressure to contribute to local development in the destination. The analysis of a complex transnational space such as a residential tourism destination can then also make us rethink some of the assumptions of development research and practice.

\section{References}

ALEDO, A. (2008), 'De la tierra al suelo: la transformación del paisaje y el Nuevo Turismo Residencial', ARBOR Ciencia, Pensamiento y Cultura, 729, 99-113.

BAUMEISTER, E., FERNÁNDEZ, E. and ACUÑA, G. (2008), Estudios sobre las migraciones regionales de los Nicaragüenses, Guatemala, Editorial de Ciencias Sociales.

BCCR (BANCO CENTRAL DE COSTA RICA, GRUPO INTERINSTITUCIONAL DE INVERSIÓN EXTRANJERA DIRECTA) (2008), Inversión extranjera directa en Costa Rica 2007-2008 preliminar (report), San José (Costa Rica), Banco Central de Costa Rica, available at http://www.bccr.fi.cr/documentos/publicaciones/archivos/Informe\%20Sobre\%20Flujos\%20de\%20Inversi\% C3\%B3n\%20Extranjera\%20Directa\%20en\%20Costa\%20Rica\%202007-\%202008\%20\%20N\%2019.doc (accessed 2 January 2009).

BENSON, M. and O'REILLY, K. (2009), 'Migration and the search for a better way of life: a critical exploration of lifestyle migration', The Sociological Review, 57, 608-625.

BOLAÑOS CÉSPEDES, F. (2009), Dictamen Jurídico y socio laboral convenio binacional Costa Rica Nicaragua (report), San José (Costa Rica), Friedrich Ebert Stiftung, available at http://library.fes.de/pdffiles/bueros/costarica/07016.pdf (accessed 18 January 2011).

CAÑADA, E. (2010), Turismo en Centroamérica: Nuevo escenario de conflicto social, Madrid, Alba Sud, available at www.albasud.org/publ/docs/32.low.pdf (accessed 1 September 2010). 
DUIM, V. R. VAN DER (2005), 'Tourismscapes. An actor-network perspective on sustainable tourism Development' (unpublished PhD Thesis), Wageningen Universiteit.

DUIM, R. VAN DER (2007), 'Tourismscapes: An actor-network perspective', Annals of Tourism Research, 34, 961-976.

EDELMAN, M. (1992), The logic of the latifundio: the large estates of northwestern Costa Rica since the late nineteenth century, Stanford University Press.

EIRENE-CENDEROS (2009), Migración de retorno: Nicaragua-Costa Rica - Nicaragua (report), San José, Costa Rica, Eirene-Cenderos, available at www.cenidh.org/files/Estudio_\%20migracion.pdf.pdf (accessed 2 January 2011).

JANOSCHKA, M. (2009), 'The contested spaces of lifestyle mobilities: regime analysis as a tool to study political claims in Latin American retirement destinations', Die Erde, 140, 251-274.

HALL, C.M. and WILLIAMS, A.M. (eds) (2002), Tourism \& migration. New relationships between production \& consumption, Dordrecht, The Netherlands, Kluwer Academic Publishers.

HEIN, W. (2002), 'Posfordismo y desarrollo regional sostenible con base en el turismo: visión de conjunto de los resultados', in E. Fürst \& W. Hein (eds), Turismo de larga distancia y desarrollo regional en Costa Rica, San Jose, Costa Rica, DEI (Asociación Departamento Ecumenico de Investigaciones), 25-82.

INEC (INSTITUTO NACIONAL DE ESTADÍSTICAS Y CENSOS, COSTA RICA) (2000), 'IX Censo Nacional de Población 2000’ (census data), San José, Costa Rica, INEC.

INEC (INSTITUTO NACIONAL DE ESTADÍSTICAS Y CENSOS, COSTA RICA) (n.d.), 'Encuestas de Hogares de Propósitos Múltiples 2004-2009' (household survey data), available at http://www.inec.go.cr/Web/Home/GeneradorPagina.aspx (accessed 2 January 2011).

MCELROY, J.L. and DE ALBUQUERQUE, K. (1992), 'The economic impact of retirement tourism in Montserrat: some provisional evidence', Social and economic studies, 41, 127-152.

MCINTYRE, N. (2009), 'Rethinking amenity migration: integrating mobility, lifestyle and socialecological systems', Die Erde, 140, 229-250.

MCWATTERS, M.R. (2009), Residential tourism. (De)constructing paradise, Bristol, Channel View.

MONGE, R., CÉSPEDES, O. and VARGAS, J.C. (2009), South-south remittances. The importance of the Costa Rica - Nicaragua corridor, San José (Costa Rica), Academia de Centroamérica, available at http://idbdocs.iadb.org/wsdocs/getdocument.aspx?docnum=35006305 (accessed 15 January 2011).

MORALES, A. and CASTRO, C. (2002), Redes transfronterizas. Sociedad, empleo y migración entre Nicaragua y Costa Rica, San José, Costa Rica, Facultad Latinoamericana de Ciencias Sociales (FLASCO).

MORALES, L. and PRATT, L. (2010), Analysis of the Daniel Oduber Quirós International Airport, Liberia, Guanacaste (report for Center for Responsible Travel, 'The impact of development associated to tourism along the Pacific coast of Costa Rica'), Washington, DC / Stanford, CA, Center for Responsible Travel, available at http://www.responsibletravel.org/resources/Coastal-Tourism.html (accessed 2 January 2011).

MORALES CHAVARRÍA, S. (2005), Pinilla y Four Seasons: baratos para extranjeros adinerados (news article), El Financiero, 24 July 2005. 
MPI (MIGRATION POLICY INSTITUTE) (2006), America's emigrants. US retirement migration to Mexico and Panama (report), Washington, MPI, available at http://www.migrationinformation.org/Feature/display.cfm?id=416 (accessed 2 May 2008).

PROGRAMA ESTADO DE LA NACIÓN (2007), 'Aporte especial: Diversidad de destinos y desafíos del turismo en Costa Rica: los casos de Tamarindo y La Fortuna', in Programa Estado de la Nación, Décimotercer informe Estado de la Nación en desarrollo humano sostenible, San José, Costa Rica, Programa Estado de la Nación, 193-224.

RAGHURAM, P. (2009), 'Which migration, what development? Unsettling the edifice of migration and development', Population, Space and Place, 15, 103-117.

ROMÁN, M. (2008), Turismo y desarrollo inmobiliario en la región Centroamericana: elementos conceptuales y metodológicos para abordar su investigación (report), San Salvador, El Salvador, PRISMA, available at http://prisma2.org.sv/web/publicacion_detalle.php?id=331 (accessed 2 January 2009).

SAlAS ROIZ, A. (2010), Polo Turístico Golfo de Papagayo, Guanacaste, Costa Rica. Análisis del Polo Turístico Golfo de Papagayo como un modelo único gubernamental de concesión turistica (report for Center for Responsible Travel, 'The impact of development associated to tourism along the Pacific coast of Costa Rica'), Washington, DC / Stanford, CA, Center for Responsible Travel, available at http://www.responsibletravel.org/resources/Coastal-Tourism.html (accessed 2 January 2011).

STEEL, G. WINTERS, N. and SOSA, C. (2011) Mobility, translocal development and the shaping of development corridors in (semi-)rural Nicaragua, International Development Planning Review, 34(4), this issue

TORRES, R.M. and MOMSEN, J.D. (2005), 'Gringolandia: The construction of a new tourist space in Mexico', Annals of the Association of American Geographers, 95, 314-335.

TSING, A. L. (2005), Friction. An ethnography of global connection, Princeton / Oxford, Princeton University Press.

URRY, J. (1990), The tourist gaze. Leisure and travel in contemporary societies, London, SAGE.

URRY, J. (2007), Mobilities, Cambridge, Polity Press.

VAN NOORLOOS, F. and ZOOMERS, A. (2010), 'Foreignisation of Land in Latin America:The case of residential tourism in Central America', unpublished paper for LASA conference.

ZOOMERS, A. (2010), Globalisation and the foreignisation of space: seven processes driving the current global land grab, Journal of Peasant Studies, 37 (2), 429-447. 